\title{
Air Pollution Makes Public Health Problem in Urban Agglomeration Environment in Poland
}

\author{
Katarzyna Sygit ${ }^{1}$, Witold Kołłąaj ${ }^{2}$, Marian Sygit ${ }^{1,3}$, Barbara Kołłątaj ${ }^{4}$, \\ Mirosława Harasimowicz-Bak ${ }^{5}$ \& Irena Dorota Karwat ${ }^{4}$ \\ ${ }^{1}$ Department of Health Education, University of Szczecin, Poland \\ ${ }^{2}$ III Chair of Paediatrics, Department of Paediatric Endocrinology, Medical University of Lublin, Poland \\ ${ }^{3}$ Institute of Rural Health in Lublin, Poland \\ ${ }^{4}$ Chair and Department of Epidemiology, Medical University of Lublin, Poland \\ ${ }^{5}$ Sanitary and Epidemiological Station in Szczecin, Poland \\ Correspondence: Katarzyna Sygit, Department of Health Education, University of Szczecin, Al. Piastów 40b bl. 6 \\ Szczecin 71-065, Poland. Tel: 48-91-444-2777. E-mail: ksygit@poczta.onet.pl
}

Received: April 30, 2011 Accepted: June 2, 2012 Online Published: June 18, 2012

doi:10.5539/ep.v1n2p112 URL: http://dx.doi.org/10.5539/ep.v1n2p112

\begin{abstract}
The development of civilization has a significant impact on the increment in environmental pollution. Particular threats to the health of people living in urban agglomerations make the unfavourable changes in atmospheric air.

The aim of this study was to describe the influence of climate (seasons, annual temperature changes) and presence of sources of air pollutants emissions on air pollutants concentrations in the selected urban agglomeration - Szczecin (Poland).

Researches were conducted at 4 air pollution monitoring stations during the period 2005-2008.

There were noticed statistically significant relationships between the air pollutants concentrations and climate parameters (wind, temperature, seasons). It was found that average annual PM10 concentrations were lower than the limit value. By contrast average daily PM10 concentrations exceed quality standards. Annual average concentrations of lead and cadmium in PM10 were lower than acceptable levels (for lead) or destination levels (for cadmium). While the average concentrations of benzo(a)pyrene in PM10 were above the target value $1 \mathrm{ng} / \mathrm{m}^{3}$. The air quality in Szczecin agglomeration improved during the period 2005-2008.
\end{abstract}

Keywords: air, pollutions, agglomeration, particulate matters PM10, seasonality, health, norms

\section{Introduction}

The more important public health problems in urban agglomerations include such threats as air pollution and traffic noise. They pose a risk to human health (Akyuz \& Cabuk, 2009), including diseases of the respiratory system (Staffs of the California Air Resources Board and the Office of Environmental Health Hazard-Assessment,1994; Brzeźnicki et al., 2009; Iwanek et al., 2007), also asthma in children (Van Otterlo \& De Koning, 2009), cardiovascular diseases (Ito et al., 1995), birth defects, cancer (Schell \& Denham, 2003) as well as premature deaths in individuals with existing heart or lung diseases. Such factors contribute to significant increases in morbidity and mortality rates in populations (Roukos et al., 2009; Dz. U., 2008).

Pollutants can be in the form of solid particles, liquid droplets, or gases. In addition, they may be natural or appear as effects of human activities (anthropogenic sources).

\subsection{Particle Pollution}

Particle pollution (also called particulate matter or PM pollutions) adversely impacts on the human body in two possible ways: directly (through inhalation or absorption of harmful substances adhered to the skin or mucous membranes) and indirectly - by causing unfavourable changes in the natural environment.

These air contaminants may pose a threat when they are present in exposed areas, and (it is often forgotten) in closed spaces, including homes (Roukos et al., 2009). For this reason it is important to conduct comprehensive 
monitoring of dust concentrations in outside and inside the living quarters.

Particle pollution is made up of number substances - a complex mixture of extremely small particles and liquid droplets - organic as well as inorganic ones. All of them may appear because of natural reasons (natural particulates), as well as human activities (anthropogenic particulates).

Natural sources of such pollutions are: volcanoes, grassland fires, surface abrasion of rocks, soil, dust storms, soil erosion, living vegetation, sea spray and so on.

Anthropogenic sources are: human activities such as burning of fossil fuels in vehicles, power plants and various industrial processes (energy industry, mining, building material industry technologies - cement production dusts constitute about $30 \%$ of the resulting material) (Silva et al., 2009). The source of these pollutants can be coal, wood, waste, biofuels and biomass used as fuel for home furnaces and central heating systems as well as petrol and diesel used by vehicular traffic means (Welker, 2007).

The harmful effects of particulates depend on the chemical structure and the diameter of particles. Particles with a diameter larger than 10 micrometres do not play a significant role in human health. Among those posing threat to human health, there can be distinguished big particles (diameter between 2.5 and 10 micrometres) - called PM10 and small particles and smaller than 2.5 micrometres - called PM2.5. Particles with an aerodynamic diameter of 5-10 micrometres are mostly captured by the nose, but less of them may reach the throat, and even the trachea. Particles with a diameter of 1-5 micrometres can penetrate into the bronchi and bronchioles. Submicron particles with a diameter less than $1 \mu \mathrm{m}$ (1000 nanometres) reach the alveoli (Tripath et al., 2009). There is evidence that particles smaller than 100 nanometres (NPs, nanoparticles) can pass through cell membranes and migrate into other organs, including the heart and the brain. NPs may induce inflammation, apoptosis and oxidative stress. It has been suggested that particulate matter can take part in pathogenesis of some degenerative brain diseases and induce similar brain damages as those found in Alzheimer patients (Win-Shwe \& Fujimaki, 2011).

Some air pollutants present in PM10 are considered as especially dangerous both to humans and to their environment. Among them there are: heavy metal ions (cadmium, lead, strontium) and many organic substances - especially derivatives of amines, nitrile compounds and polycyclic aromatic hydrocarbons (PAHs) (Schell \& Denham, 2003; Roukos et al., 2009; Dz. U., 2008; Silva et al., 2009). PAHs levels in air, water and soil (Dz. U., 2008; Tripath et al., 2009) and in foodstuffs (like vegetables (Brzeźnicki et al., 2009)) depend mainly on pollutions emitted by vehicular transportation (Welker, 2007). PAHs are known for their carcinogenic, mutagenic and teratogenic properties. High prenatal exposure to PAH is associated with lower IQ in children and with childhood asthma (Welker, 2007).

\subsection{Polycyclic Aromatic Hydrocarbons}

Polycyclic aromatic hydrocarbons (PAHs) are pollutants of human environment and may be find in natural crude oil and coal deposits as well as in solid impurities from the coke industry. The largest source of PAHs is - the incomplete combustion of fossil fuels and their processing. The emissions of PAHs depend mainly on the fuel quality, and on the combustion conditions.

Some PAHs, after entering the human body (via the respiratory tract or the skin or mucous membranes) are converted to derivatives being mutagenic and carcinogenic substances. Such information concerns at least six of polycyclic aromatic hydrocarbons: benzo(a)pyrene, methylphenantrene, cyclopenta(c,d)pyrene, benzo(a)anthracene, dibenzo(a,c)anthracene and dibenzo(a,h)anthracene.

Benzo(a)pyrene (B(a)P) is the most studied of the PAH family of compounds. It is a substance of particular clear high carcinogenic potency (Schell \& Denham, 2003). Environmental Toxicology Committee of the Polish Academy of Sciences in Poland found polycyclic aromatic hydrocarbons as the most dangerous environmental carcinogenic poison.

The atmospheric air contains $0.5 \%$ of total PAHs content present in environment. The sources of atmospheric PAHs are both natural and anthropogenic. The main sources of polycyclic aromatic hydrocarbons in the air are (Van Otterlo \& De Koning, 2009):

- incomplete combustion of fossil fuels;

- volatile dusts and ashes resulting from the combustion of fuels or waste disposal;

- heavy industry activities concerned with the coal and oil processing. 


\subsection{Cadmium}

Cadmium is a toxic element which is easily absorbed from intestines and accumulating in almost all of the organs. At molecular level, cadmium interferes with the utilization of essential metals e.g. $\mathrm{Ca}, \mathrm{Zn}, \mathrm{Se}, \mathrm{Cr}$ and $\mathrm{Fe}$. Whatever its presence in food is considered as undesirable. The steel industry and waste incineration, followed by volcanic action, zinc and phosphate fertilizers production as well as sewage sludge and coal combustion are estimated to be main sources of atmospheric cadmium (Dz. U., 2008).

\subsection{Lead}

Lead compounds are toxic to many organs and tissues including the heart, bones, intestines, kidneys, and reproductive and nervous systems. It interferes with the development of the nervous system and causes brain degeneration. It is particularly toxic to children, causing potentially permanent learning and behaviour disorders. Some medical studies suggest that leads salts are carcinogenic to humans. The main sources of lead contamination of the urban environment are cars (leaded fuel) and iron as well as steel industries (Iwanek et al., 2007; Tripath et al., 2009).

The review of the world literature clearly indicates the impact of air pollution on human health (incidence of many diseases, increased mortality, inborn body malformations). The results of studies, conducted in different countries and continents, indicate a high and still increasing problem of air pollution in urban agglomerations, including Polish agglomerations.

The detailed analyses suggest diversity of the health status of people living not only in different areas of the country, but also in various districts of large cities. Such observations suggest implication of local environmental factors, including microclimate and local air pollutants (such as including cadmium, lead and benzo(a)pyrene) emissions.

Precise knowledge of the causes of local variations in population health and analyses based on the selected descriptive variables (such as the air concentration of selected toxic compounds) - may help in developing guidelines for continuous monitoring of air pollution in urban agglomerations and analysis for targeting preventive activities.

The aim of this study was:

- Description of the occurrence of air pollution in selected urban agglomeration (Szczecin, Poland) in relation to:

a. seasons, annual temperature changes

b. resultant emissions from point sources located in the city as well as from considered fugitive emissions from means of communication/transport

c. emissions from surface sources (local boiler houses and individual home furnaces)

- Outline areas (districts) in Szczecin urban agglomeration with expected higher air pollution.

\section{Material and Methods}

\subsection{Material}

Material were samples of air taken in a representative Polish urban agglomeration - in Szczecin (405 000 inhabitants; 2 small shipyards, sea port, phosphate fertilizers factory, foundry which was in the period of liquidation). The mesaurements were continued during the period 2005-2008.

Locations of stations measuring air pollutants for assessing air quality in Szczecin (measuring posts named Pkt1, Pkt2, Pkt3, and Pkt4) are described by Figure 1.

\subsection{Methods}

There was used automatic and manual monitoring equipment to take samples of air.

The PM10 concentrations and their chemical content were determined by using automated and manual monitoring equipment. In two stations (Pkt1 and Pkt2) the tests were carried out by using method of beta radiation absorption, in stations named Pkt3 and Pkt4 - by using gravimetric method.

The localisations of Pkt.1 - Pkt4 station are schematically illustrated in Figure 1.

Measurements of cadmium and lead content in particulate matter PM10 were done by using atomic absorption spectrometry, the measurement of benzo(a)pyrene content - by using high performance liquid chromatography equipment. 


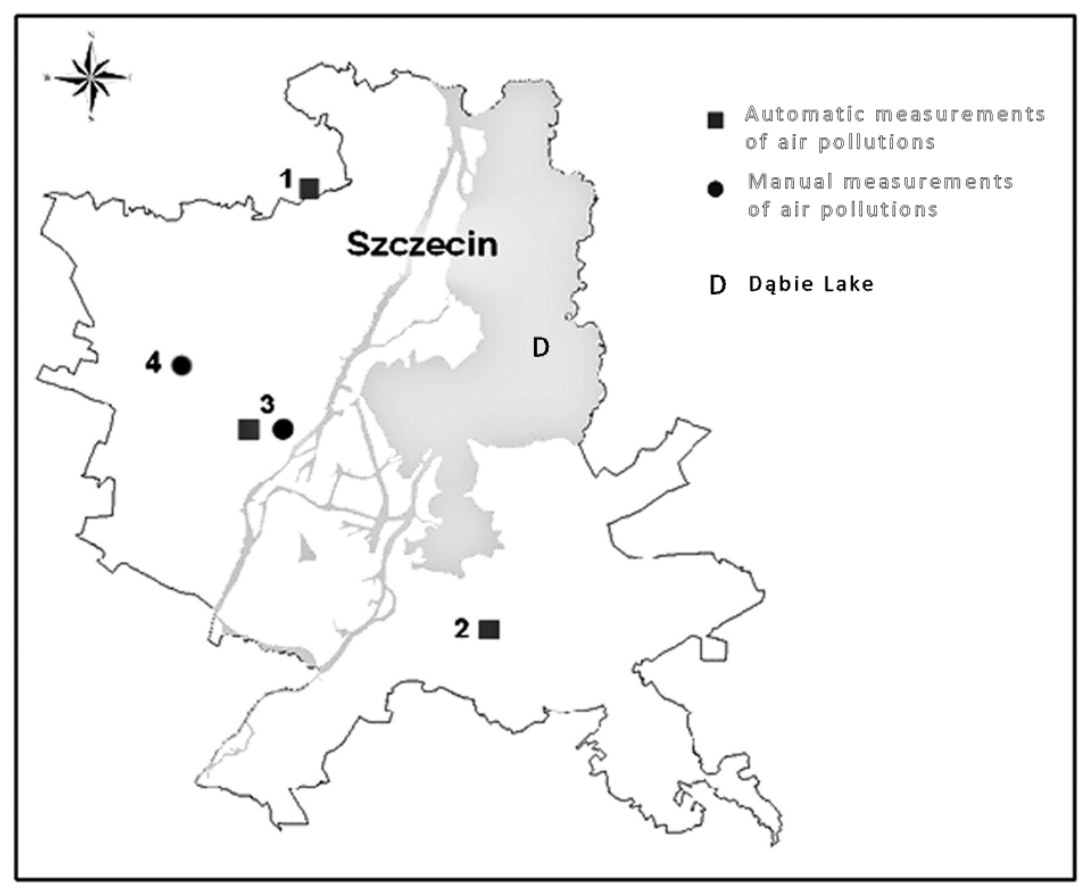

Figure 1. Locations of air quality monitoring stations (numbers 1-4) in Szczecin agglomeration

\subsubsection{Power Analysis and Statistical Analysis of Obtained Data}

Power analysis of trends was used for detecting trends. To calculate the trend lines the exponential equation: $\mathrm{y}=\mathrm{cxb}$ was used. Plotted line is most reliable when its R2 value is equal (or almost equal) to 1 .

Mathematical modelling of the distribution of concentrations was performed by using a CALMET - CALPUFF modelling system (Scire et al., 1998; Scire et al., 2000). Such system was used to describe concentrations of pollutants coming from point, linear and surface sources of changeable emissions, to describe the impact of selected emitters on pollutants concentration or to determine areas that one can expect unfavourable health effects caused by air pollutions.

Mentioned CALMET - CALPUFF modelling system is the last generation of a large set of pre-processing programs enabling detailed analysis of geographical as well as meteorological databases and presenting temporal variability of meteorological conditions as three-dimensional cloud images.

This is a multi-layered, non-stationary model in the system Lagrange A. In this model, it is assumed that the emitted pollutant load is divided into partial loads placed on the air at certain time intervals $\Delta$ t. These charges (the clouds), they move independently of one another according to local meteorological conditions. This feature allows for very accurate description of the variability of emission sources/fields (every cloud may contain different pollution load). Each pollutant emitted a cloud moves independently from the others throughout the computational grid. For this reason, this model uses the additional meteorological pre-processors, whose tasks are to accurate description of the local meteorological parameters.

Both the CALMET meteorological pre-processor and CALPUFF modelling system required the following data: land use categories and land surface properties such as: land elevations, terrain roughness factor, albedo (the ratio of reflected to incident radiation), Bowen ratio (the ratio of heat absorbed by the water surface to the amount of heat used for evaporation), the heat transfer in the soil, and the index of biological activity.

These data were prepared for the points which coincided with the grid coordinates used to determine the meteorological parameters.

CALMET meteorological pre-processor calculates the coordinates of the system depending on the vertical axis of the terrain and define them as "Z"-values (1):

$$
\mathrm{Z}=\mathrm{z}-\mathrm{ht}
$$

where: 


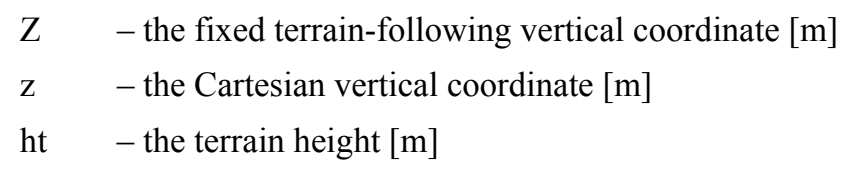

The vertical wind velocity, $\mathrm{W}$ was calculated using the formula (2):

$$
W=w-u \frac{\partial h_{t}}{\partial x}-v \frac{\partial h_{t}}{\partial y}
$$

where:

$$
\begin{aligned}
& \mathrm{W} \quad \text { - the vertical wind velocity }[\mathrm{m} / \mathrm{s}] \\
& \mathrm{w} \quad \text { - the physical vertical wind component }[\mathrm{m} / \mathrm{s}] \text { in Cartesian coordinates } \\
& \mathrm{u}, \mathrm{v}
\end{aligned}
$$

\section{Results}

The air quality in studied agglomeration depended on:

- high emissions sources (points) activities:

-sources located in the city (especially in its southern part and along the Odra River to the north towards the issue)

-fugitives from linear sources (road traffic pollutants emission),

- $\quad$ surface sources emissions (local boiler houses or boiler rooms and individual home furnaces)

- pollution blown by winds from areas situated outside the urban boundaries.

The impact of pollutants emitted by point emitters on air quality in the studied agglomeration depended on the prevailing wind directions. A wind rose situated in the measurement point named Pkt1, considered as an urban wind background, showed that the south western winds were predominant $(39.2 \%)$, other winds directions were less frequently observed - among them the north-east (19.5\%), and north ones (19.4\%). Therefore, in addition to local sources, a significant impact on air quality in studied agglomeration had emissions coming from the neighbouring areas and sources located in Germany (load of pollutants carried by winds blowing from the west).

Pollutants emitted by vehicles implicated not only air pollution in areas situated near traffic routes, but also took part in the photochemical reactions occurring in the atmosphere, influencing the increase in concentrations of tropospheric ozone.

\subsection{PM10 in Air}

The linear pollution sources emitted about $20 \%$ of PM10 present in urban air.

However, in the centre of the Szczecin agglomeration, the biggest impact on the total load of PM10 coming from fuel combustions had emissions being effects of community heating activities. In some areas of Szczecin agglomeration the percentage of the PM10 coming from such sources accounted for up to $60 \%$ of the total PM10 present in polluted air.

European Union set in 1999 air quality standards for PM10 particles. The annual average value should not exceed $40 \mu \mathrm{g} \mathrm{m} 3$ and the $50 \mu \mathrm{g} \mathrm{m} 3$ daily average values must not be exceeded more than 35 times during the year.

The studies concluded that there were no exceedances of recommended annual average concentrations at all measuring points in the analysed period. The highest average concentration occurred in 2006, at measuring the point "Pkt. 3" - $33.7 \mu \mathrm{g} / \mathrm{m} 3$, the lowest was recorded in 2008, at the measuring point "Pkt. 1" - $14.2 \mu \mathrm{g} / \mathrm{m} 3$.

The Figures 2, 3, 4, 5, 6 and 7 present the changes in PM10 concentration in air in the period of 2005-2008. 


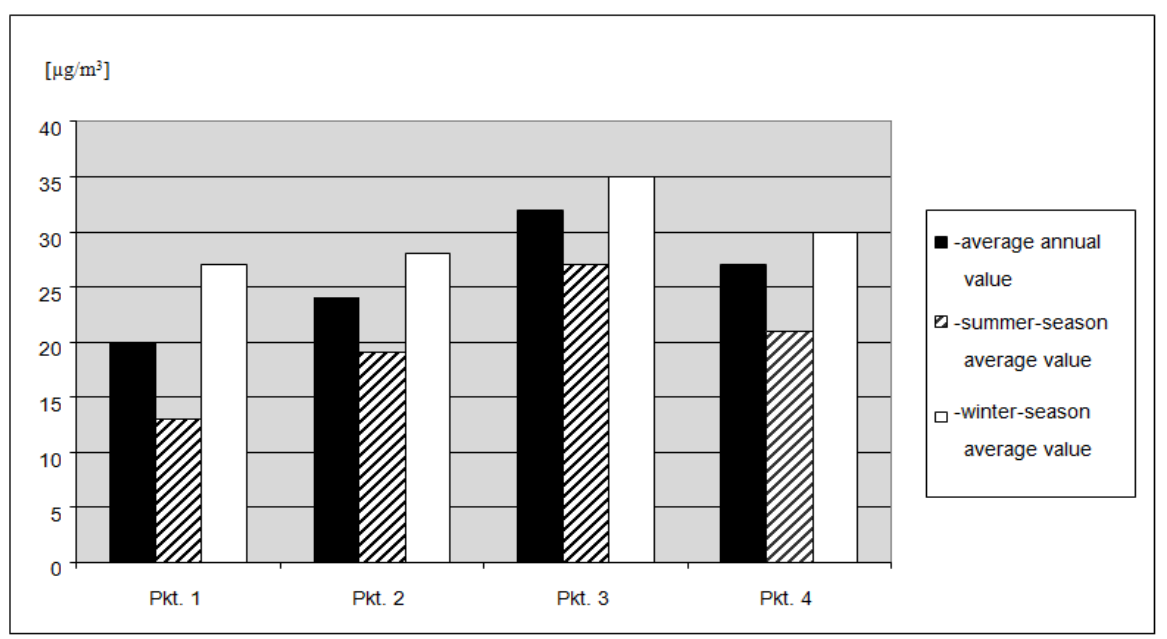

Figure 2. PM10 concentrations $\left[\mu \mathrm{g} / \mathrm{m}^{3}\right]$ in air, in 2005 , measured as average annual as well as winter-season and summer-season average values

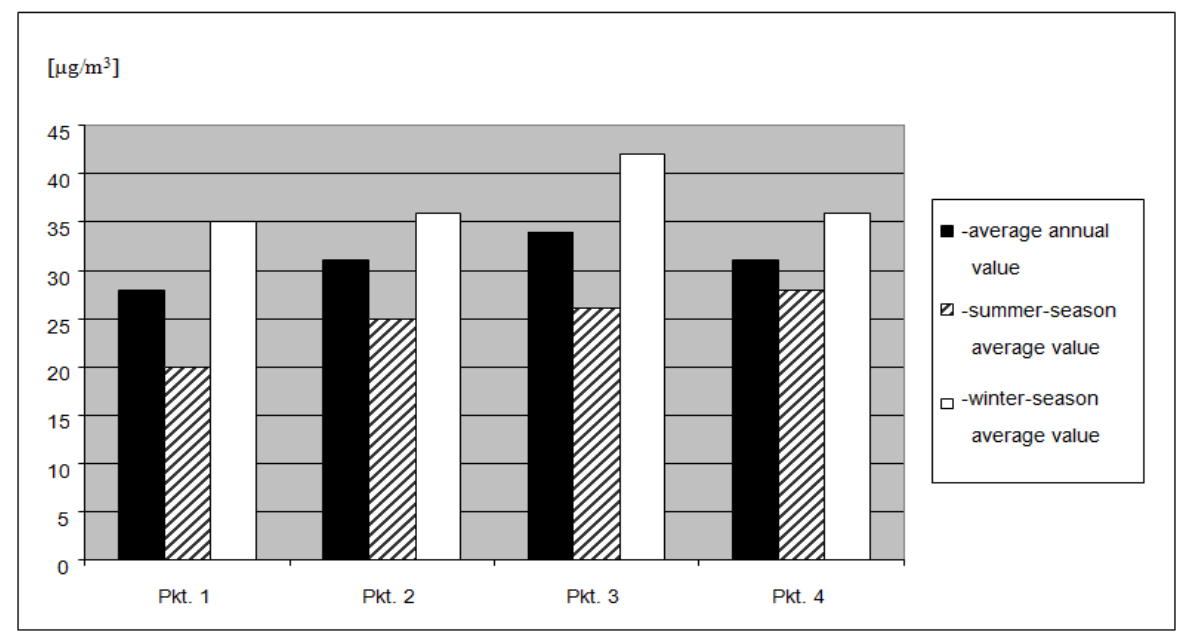

Figure 3. PM10 concentrations $\left[\mu \mathrm{g} / \mathrm{m}^{3}\right]$ in air, in 2006, as average annual as well as winter-season and summer-season average values

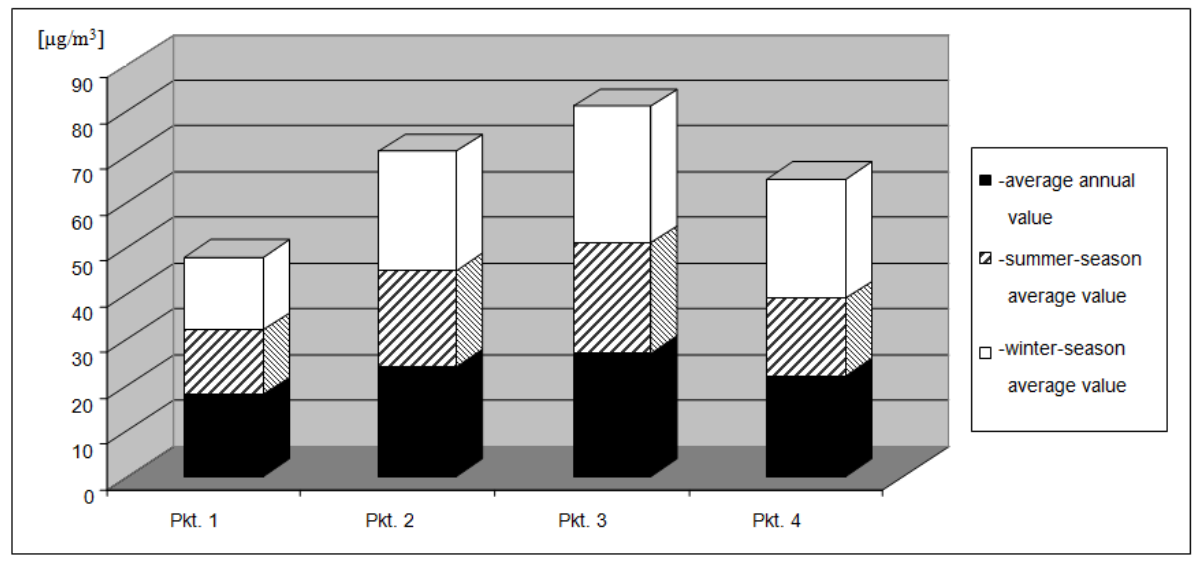

Figure 4. PM10 concentrations $\left[\mu \mathrm{g} / \mathrm{m}^{3}\right]$ in air, in 2007, as average annual as well as winter-season and summer-season average values 


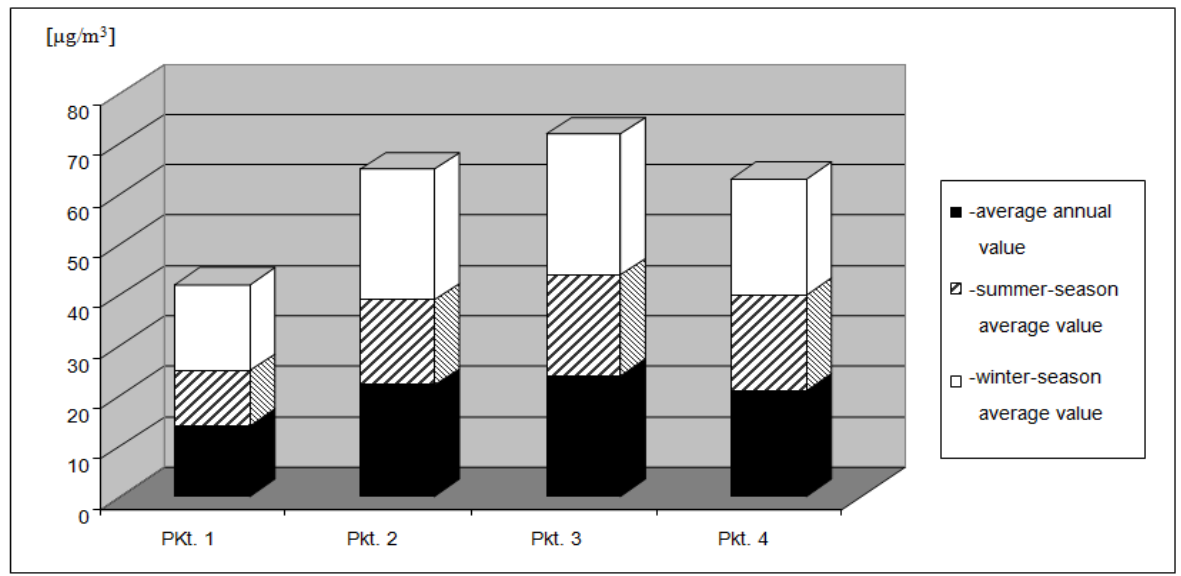

Figure 5. PM10 concentrations $\left[\mu \mathrm{g} / \mathrm{m}^{3}\right]$ in air, in 2008, as average annual as well as winter-season and summer-season average values

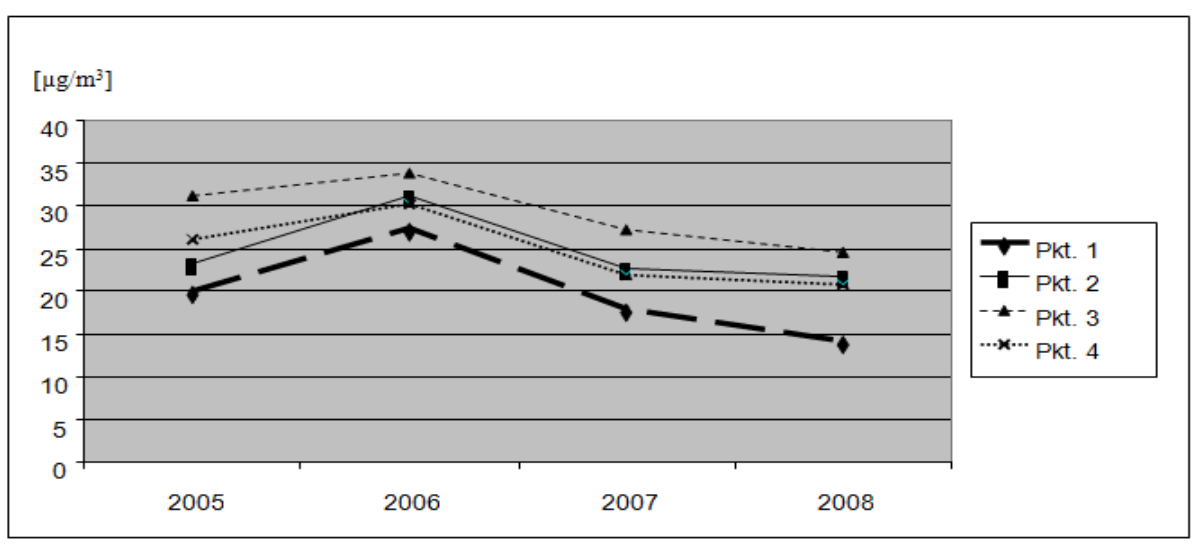

Figure 6. Average annual PM10 concentrations $\left[\mu \mathrm{g} / \mathrm{m}^{3}\right]$ in air, in 2005-2008

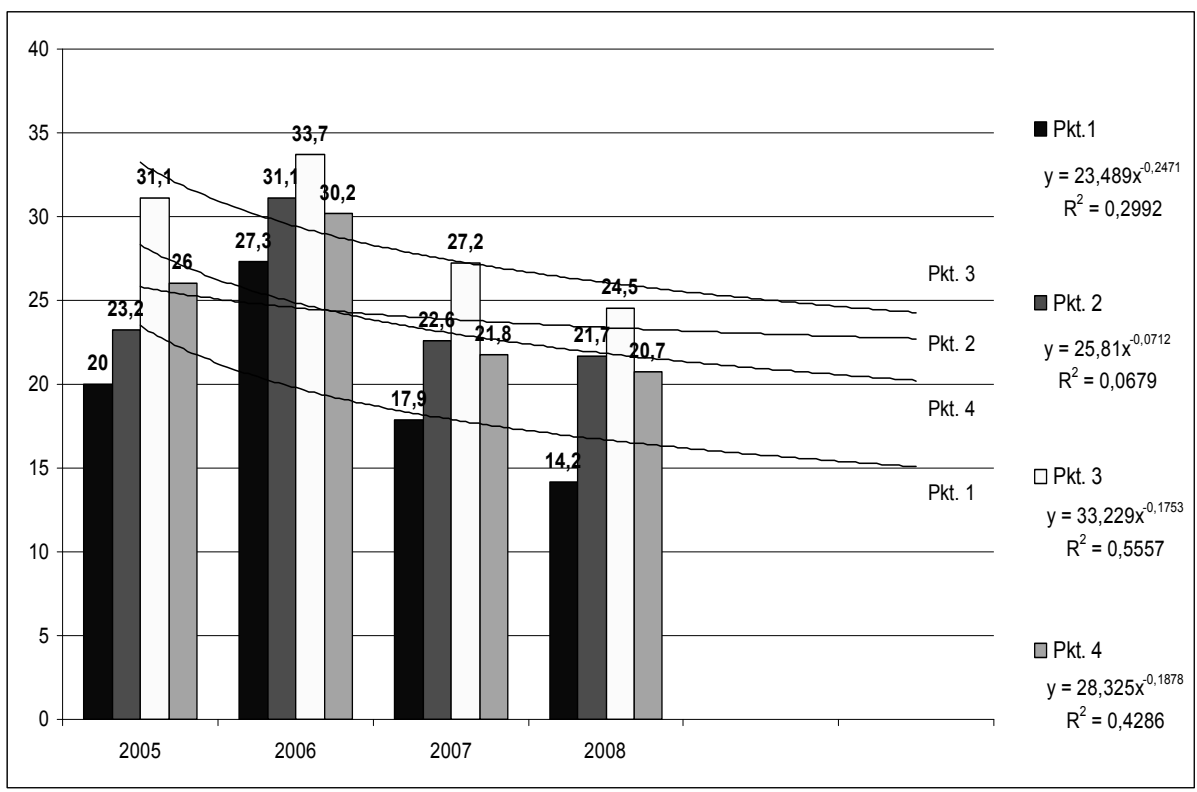

Figure 7. Average annual PM10 concentrations 
Analysis of these data allows to draw the conclusions that the concentrations of particulate matter PM10 was dependent on seasonality - winter season showed an increase of particulate matter concentrations by $20 \%$, while in summer the concentrations were lower by about 20\%. The PM10 concentrations depended on temperature, too. The lowest average air temperature was noticed in the first quarter of 2006. That year, the highest concentrations of PM10 contaminants in air were noticed, too (Figure 8).

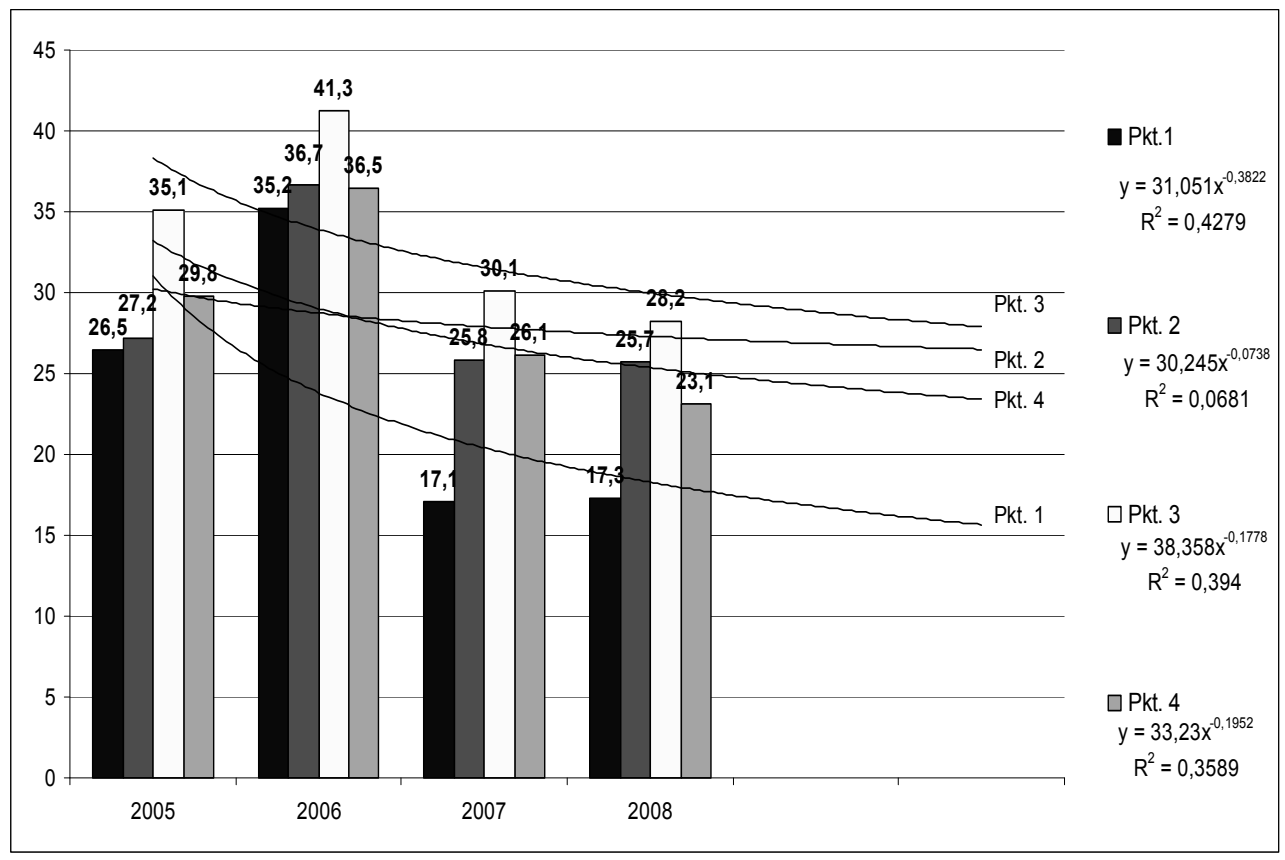

Figure 8. Average PM10 concentrations during winter seasons

Despite the fact that the mean annual and seasonal concentrations of PM10 were within normal limits, periodically, in 24-hour samples, the concentrations of such pollutants were above the upper acceptable limits.

Such incidences were registered in 2005 by the pollution monitoring station named Pkt. 3 and in 2006 - by stations Pkt. 2, Pkt. 3 as well as Pkt. 4.

Most exceedances occurred in January and February, when low air temperatures were noticed. Such exceedances were primarily due to increased emissions coming from domestic heating systems. In 2007 and 2008, such exceedances (in 24-hour samples) were also noticed, but the number of such episodes was 35 times smaller than in 2005 and 2006.

During summer seasons the PM10 concentrations in air were within the normal (recommended) limits.

The Figures 6 and 7 present analysis of the trend lines for average concentrations of particulate matter PM10 described as average annual as well as seasonal average values.

In the first quarter of 2007 average temperature was much higher than in the identical period of last year. This resulted in much lower concentrations of pollutants presence in air.

\subsection{Lead in PM10 in Air}

Measurements of lead concentrations in the air - its contents in PM10- were continued during the period of 2005-2008. The pollution monitoring station named Pkt. 4 had never recorded levels of lead exceeding the permissible limits (maximum acceptable concentration -MAC- for lead in air is equal to $0.5 \mu \mathrm{g} / \mathrm{m} 3$ ). The average annual concentrations of lead were close to $2 \%$ to $5 \%$ of MAC for such element in air.

\subsection{Cadmium and Benzo(a)pyrene in Particulate Matter PM10 in Air}

Cadmium measurements were carried out in 2005-2008. Bezno(a)pyrene measurements were carried out in 2006-2008 (in the pollution monitoring station named Pkt. 4) and in 2007-2008 in the pollution monitoring station named Pkt 3.

In Poland, the Regulation of the Minister of Environment dated 3 March 2008 on the levels of certain substances in the air, specifies the maximum permissible concentration of pollutants in air. Such recommendations are 
considered as target values that should become the norm in 2013.

The registered average annual concentrations of Cd in air (in PM10) in 2005-2008 were below a targeted value.

The average annual concentration of $\mathrm{B}(\mathrm{a}) \mathrm{P}$ in air were decreasing, but still remained above the target value. The highest average annual concentrations of $\mathrm{B}(\mathrm{a}) \mathrm{P}$ were registered by the pollution monitoring station named Pkt. 4 . There were observed seasonal variations of $\mathrm{B}(\mathrm{a}) \mathrm{P}$ concentrations in air - higher concentrations during heating seasons.

\section{Discussion}

Pollutants emitted to the atmosphere constitute a significant hazard to human environment due to an uncontrolled spread and to a negative impact on living organisms, buildings (dust, acid rains) and other elements of the environment (Akyuz \& Cabuk, 2009).

Air pollutions inhaled by lungs or absorbed by skin or mucous membranes pose a major risk factor for the circulatory (Ito et al., 1995), malignant (Schell \& Denham, 2003) and allergic (Van Otterlo \& De Koning, 2009) diseases appearance or worsening of such diseases courses. Children and the elderly suffering from asthma, allergies or other respiratory diseases are most at risk from poor air quality. But even healthy adults can experience adverse symptoms with as little as a single exposure to polluted air.

Constant monitoring of air, by revealing the presence of such threats, mobilizes decision-makers and municipal departments to take on actions leading to health risks reduction.

\subsection{Evolutionary Changes in the Quantity and quality of Air Pollution in Urban Environments}

The main sources of emissions in big agglomerations are: energy, industrial, municipal and household sectors, transport, communications and industrial technologies (Staffs of the California Air Resources Board and the Office of Environmental Health Hazard-Assessment., 1994).

In recent years, because of the rapid development of road transport, such source of pollutants took increasingly important role in urban environmental pollution, and altered the proportions of the various toxins in the air and, consequently, in soil, water and food. Despite improvements in technology and the technical condition of vehicles, the barrier to reduce emissions from this source is small capacity of streets, causing traffic difficulties, creating a traffic jams, and thus, increasing the excretion of contaminants (Van Otterlo \& De Koning, 2009).

It is worth pointing out that the systematic development of the Polish economy in terms of GDP (Gross Domestic Product) has not resulted in an increase in atmospheric emissions. This is the result of the increasing use of environmentally friendly technologies, highly efficient filtration devices and switching to a higher-quality fuel.

In the sector of households they can be noticed some small effects of the implementation of guidelines for the replacement of old highly polluting heat generators using crude coal with gas or oil stoves, and improving the thermo modernization of buildings.

\subsection{Legal Regulations in Poland}

Poland has placed high priority on controlling air pollution. The newest standards of air pollution emission from the combustion of solid fuels were approved by the Polish State Environmental and adequate regulations were introduced on 20th December 2005 by Polish Ministry of Environment.

Air pollution problems have been clearly identified, and priorities, goals and targets have been defined at the highest government level and have received public support.

Regardless of the approved national legislation, Poland undertook to comply with the recommendations of the European Union, and to apply gradual reduction of air pollutants emissions from manufacturing activities.

Since joining the European Union in 2004, Poland implemented the air quality monitoring and assessment requirements according to the EU Air Quality Law.

4.3 Air Pollutants Concentration in Air of Szczecin Agglomeration during the First Years of Attempts Leading to Reduction of Air Pollution emission from the Combustion of Solid Fuels

\subsubsection{PM10}

Air pollution studies have been conducted during the four years of preparation (2005) and implementing the new guidelines on air pollution standards (2006-2008) concerning air pollution emission from the combustion of solid fuels (regulations approved by the Polish State Environmental and introduced on 20th December 2005).

Like in other Polish agglomerations (Brzeźnicki et al., 2009), decision makers in Szczecin (Landsberg Uczciwek, 2007; Landsberg-Uczciwek et al., 2009) started the implementation of activities aimed primarily at: 
- limiting PM10 emissions from large installations

- reducing emissions from the surface sources (communal-household sector)

- reducing emissions from transport and communication

- environmental education implementation to force proper social behaviours such as energy saving and usage of good quality of heating fuels.

Because such changes required large financial outlays, including time-consuming changes of modernization and adaptation, the effects had to occur slowly, evolutionarily.

The preformed study revealed that in the analysed period (2005-2008) there was a decrease in the number PM10 - carrier of toxic substances such as adsorbed PAHs, $\mathrm{Pb}$ and $\mathrm{Cd}$ (Figure 6).

In other Polish urban areas with less developed industry such tendencies were present, too. For example, in Lublin (350 000 inhabitants, only two industrial plants employing more than 500 workers: POL-MOT SA-factory - producer of farm machines and delivery trucks; SIPMA - farm machinery factory, and only one large power plant) the tendencies were similar. In Lublin, at this time, the fall in average annual average PM10 concentrations - from 37.4 to $29.4 \mathrm{ug} / \mathrm{m}^{3}$ - was noticed, too (Żelazny et al., 2009; Struski, 2010).

Attempts to improve the air quality were made by the relevant authorities in various Polish regions, but not all the results were positive. In areas of greater industrialization, in urban areas with large quantities of fossil carbon usage (steelworks, coking plants, large power plants and power plants, coal processing plants) rapid changes involving the replacement of polluting technologies with new and more environmentally friendly ones were impossible. So, for example, in Małopolskie and Śląskie Provinces (agglomerations: Katowice, Zabrze, Tychy, Kraków) there were not noticed any essential changes in PM10 concentrations in air in the period of 2005-2008 (Ośródka, 2011).

The analyses of the dependence of occurrence of air pollution in Szczecin, suggest higher concentrations of PM10 in the air during the heating seasons (January-March, October-December) than in summer (April-September). Seasonal concentrations were more evident in the place located away from traffic (point Pkt. 1) than in other measurement positions in Szczecin, located in the vicinity of the impact of auto exhausts. This indicated that the emissions from domestic heating surfaces as well as auto exhausts were playing an important role in the formation of the pool of PM10 present in air of large cities.

Quite similar observations were done in Lublin (Polish agglomeration with a somewhat similar state of economic development and economic activity) (Struski, 2010).

\subsubsection{Lead}

The lead air pollution is known as a typical side effect of modern civilization development. Until the implementation of laws ordering to cease the usage of fuels containing lead, the main sources of lead present in air were: industrial processes and leaded fuel used by means of transportation. The contributions of each source to local pollution were different in different countries according to the type and number of local industrial processes, density and age of road transport and local weather conditions.

Unleaded petrol was introduced in the 1980's. Since 1986, all brand new cars, produced in the USA and then in many European countries, were equipped with fuel systems designed to use only unleaded fuel (so called "post-1986 cars"). In the USA, from 1 January 1996, the Clean Air Act banned the sale of leaded fuel for use in on-road vehicles. In Poland, in 2005, the two largest Polish oil companies: PKN Orlen and Grupa Lotos ceased production of leaded gasoline.

The years 2005 - 2008 can be regarded as a period where the risk of air pollution by lead coming from the combustion of leaded fuels were impractical or extremely unlikely.

In 1987, according to WHO data, the average concentration of lead in air was close to: $0.5 \mathrm{mg} / \mathrm{m}^{3}$ in the vicinity of villages and around towns and $0.5-3.0 \mathrm{mg} / \mathrm{m}^{3}$ while in the vicinity of large cities in Europe (WHO, Regional Office for Europe, 1987; Kucharski, 1988).

The ban on leaded fuel sales and deployment of unleaded gasoline has significantly improved air quality in European cities. In 2007, all over Poland, in 12 metropolitan areas and 15 cities with populations over 100000 inhabitants, there has been noticed only a single case of exceedance of limit values for air pollution caused by the presence of lead compounds (maximum acceptable concentration - MAC- for lead in air is equal to $0.5 \mu \mathrm{g} / \mathrm{m}^{3}$ - (Dz. U., 2008)).

In Szczecin, the average annual concentrations of lead were close to $2 \%$ to $5 \%$ of MAC for such element in air. 


\subsubsection{B(a)P}

The main source of benzo(a)pyrene in the air is incomplete combustion of solid fuels, especially coal and firewood. B(a)P may be found as pollutant of both gasoline and diesel. Such compound may be found in unleaded, premium unleaded and leaded petrol at a (presumably typical) concentration of $0.3 \mathrm{mg} / \mathrm{kg}$. Combustion of gasoline and diesel oil generates significant amounts of $\mathrm{B}(\mathrm{a}) \mathrm{P}$ (emissions from diesel engines contain higher amounts of B(a)P than those from gasoline engines), on the other hand, on average 36 per cent of the benzo(a)pyrene in an automobile's exhaust gas comes from the benzo(a)pyrene originally in the gasoline (Begeman \& Colucci, 1968).

The development of civilization is associated with the development of road transport. Observed the rapid growth the number of cars moving through the streets of big cities inevitably leads to increase the amount of $\mathrm{B}(\mathrm{a}) \mathrm{P}$ polluting the air.

The attempts to reduce the usage of solid fuels by industry, public sector (heating) as well as by households is therefore insufficient to achieve satisfactory reduction in levels of B(a)P in air.

During the period of 2006-2008, all over Poland, in most measuring points in Polish cities, there were noticed periodic exceedances of target $\mathrm{B}(\mathrm{a}) \mathrm{P}$ concentrations in air. The average annual concentration of $\mathrm{B}(\mathrm{a}) \mathrm{P}$ exceeded the target value $\left(1 \mathrm{ng} / \mathrm{m}^{3}\right)$ in 24 of 29 measuring stations located in nine metropolitan areas and in 10 cities with more than 100 thousand inhabitants.

Against this background, the values obtained in Szczecin (the average annual concentration of B(a)P in air were above target value) can be considered typical for the Polish reality.

Such a large number of exceedances of the recommended (target) values may be explained by both high emissions of $\mathrm{B}(\mathrm{a}) \mathrm{P}$ from small furnaces in communal and household sectors, increasing pollution caused by increasing automobile traffic as well as by the fact that mentioned target values are very difficult to achieve (Ito, Kinney, et al., 1995).

The observed seasonality (both Szczecin and in other Polish agglomerations) of B(a)P concentrations in air (higher during heating seasons) indicates that still remains a large number of out-dated heating equipment (both in the municipal sector, as well as individual households) in general use.

\subsubsection{Cadmium}

Cadmium emissions to air arise, in decreasing order of importance, from the combustion of fossil fuels, iron and steel production, non-ferrous metals production and municipal solid waste combustion. Cadmium emissions caused by industrial activities are closely controlled by national occupational exposure standards.

In Szczecin, the highest concentrations of cadmium in particulate matter were recorded in 2006. In that year, there were also registered the lowest temperatures in the winter air. This link shows that the cadmium concentration depended on weather conditions and thus on the impact of emissions from domestic and municipal heating surfaces.

\section{Conclusions}

The analysis of the results showed that:

(1) Air pollution in urban areas, such as Szczecin, makes a health problem for inhabitants.

(2) There were noticed statistically significant relationships between the air pollutants concentrations and climate parameters (wind, temperature, seasons).

(3) In Szczecin agglomeration, the annual PM10 levels as well as cadmium and lead concentrations in PM10 were within acceptable standards.

(4) The average annual concentrations of B(a)P in air gradually decreased but still exceed the target value.

(5) The air quality in Szczecin agglomeration improved during the period 2005-2008.

\section{References}

Begeman, C. R., \& Colucci, J. M. (1968). Benzo(a)pyrene in gasoline partially persists in automobile exhaust. Science, 161(3838), 271-275. http://dx.doi.org/10.1126/science.161.3838.271

Akyuz, M., \& Cabuk H. (2009). Meteorological variations of PM 2.5/PM 10 concentrations and particle-associated polycyclic aromatic hydrocarbons in the atmospheric environment of Zonguldak, Turkey. J Hazard Mater, 170(1), 13-21. http://dx.doi.org/10.1016/j.jhazmat.2009.05.029

Brzeźnicki, S. Bonczarowska, M., \& Gromiec, J. (2009). Occupational exposure limits for polycyclic aromatic 
hydrocarbons. Current legal status and proposed changes. Medycyna Pracy, 60(3), 179-185.

Dz. U. (2008). Rozporządzenie Ministra Środowiska z dnia 3 marca 2008 w sprawie poziomów niektórych substancji w powietrzu. Dz. U. z 2008 r. 47. 281.

Ito, K. Kinney, P. L., \& Thurston, G. D. (1995). Variations in PM-10 Concentrations Within two Metropolitan Areas and Their Implications for Health Effects Analyses. Inhal Toxic, 7, 735-745. http://dx.doi.org/10.3109/08958379509014477

Iwanek, J., Kobus, D., \& Mitosek, G. (2007). Wybrane problemy zanieczyszczenia powietrza w Polsce 2006 rok. In. w: GIOŚ. Zanieczyszczenie powietrza $w$ Polsce w latach 2005-2006. Biblioteka Monitoringu Środowiska GIOŚ. Warszawa.

Kucharski, R. (1988). Profilaktyka ekologiczna terenów przemysłowych $w$ aspekcie zmniejszenia narażenia czlowieka. Warszawa, Wydawnictwa Geologiczne.

Landsberg - Uczciwek, M. (2007). Lista działań dla poprawy jakości powietrza w Szczecinie -Ograniczenie zanieczyszczenia powietrza pytem PM10. Międzyzdroje, 6.09 - 7.09. 2007 r., Wojewódzki Inspektorat Ochrony Środowiska w Szczecinie.

Landsberg-Uczciwek, M. Rewaj, R. Pałyska, R., \& Szczepankiewicz M. (2009). Roczna ocena jakości powietrza dla województwa zachodniopomorskiego - raport za 2008 rok. Szczecin, Zachodniopomorski Wojewódzki Inspektor Ochrony Środowiska .

Ośródka, L. (2011). Projekt "Klima”. Wpływ zmian klimatu na gospodarkę i spoleczeństwo. Katowice- Kraków, Instytut Meteorologii i Gospodarki Wodnej w Krakowie.

Roukos, J., Plaisance, H., Leonardis, T., Bates, M., \& Locoge, N. (2009). Developmend and validation of an automated monitoring ststem for oxygenated volatile organic compounds and nitrile compounds in ambient air. J. Chromatogr. A, 1216(49), 8642-8651. http://dx.doi.org/10.1016/j.chroma.2009.10.018

Schell, L. M., \& Denham, M. (2003). Environmental pollution in urban environments and human biology. Annu Rev Anthropol, 32, 111-134. http://dx.doi.org/10.1146/annurev.anthro.32.061002.093218

Scire, J. S., Strimaitis, D. G., \& Yamartino, R. J. (1998). A User's Guide for the CALPUFF Dispersion Model (Version 5.0) - DRAFT. Concord, MA: Earth Tech, Inc.

Scire, J. S. Robe, F. R. Fernau, M. E., \& Yamartino R. J. (2000). A User`s Guide for the Calmet Meteorological Model. Concord, MA: Earth Tech. Inc.

Silva, I., Santos, E., Menezes, C., Faria, A., Francisco, E., Grossman, M., \& Dirrant, L. (2009). Bioremedition of a polyaromatic hydrocarbon contaminated soil by native soil microbiota and bioaugmentation with isolated microbial consortia. Biores Techno, 100(20), 4669-4675. http://dx.doi.org/10.1016/j.biortech.2009.03.079

Struski, St. (2010). Sprawozdanie z realizacji programu ochrony powietrza dla miasta Lublin. Departament Rolnictwa i Środowiska, Lublin. Retrieved March 2, 2012 from http://www.mos.gov.p1/g2/big/2012_01/4168bc42c058866e20c78443580e50f9.pdf

Staffs of the California Air Resources Board and the Office of Environmental Health Hazard-Assessment. (1994). Benzo[a]pyrene as a toxic air contaminant. Scientific review panel, April 1994. Retrieved March 2, 2012 from http://www.arb.ca.gov/toxics/id/summary/bap.pdf

Tripath, R., Kumar, R., Mudiam, M., Patel, D., \& Mehari, J. (2009). Distribution, sources and characterization of polycyclic aromatic hydrocarbons in the sedyment of the river Gomti, Lucknow, India. Bull Environ Contam Toxicol, 83(3), 449-454.

Van Otterlo, W. A., \& De Koning, C. B. (2009). Metathesis in the synthesis of aromatic compounds. Chem Rev., 109(8), 3742-3782. http://dx.doi.org/10.1021/cr900178p

Welker, A. (2007). Occurrence and fate of organic pollutants in combined sewer system and possible impacts on receiving waters. Water Sci Technol, 56(10), 141-148. http://dx.doi.org/10.2166/wst.2007.755

WHO, Regional Office for Europe. (1987). Air Quality Guidelines for Europe. WHO Regional publications, European Series. 23.

Win-Shwe, T. T., \& Fujimaki, H. (2011). Nanoparticles and Neurotoxicity. Int J Mol Sci., 12(9), 6267-6280. http://dx.doi.org/10.3390/ijms12096267

Żelazny, L., Balcerek, Z., Brudzicki, M., Buszewska-Rydzik, E., Grzywaczewska, T., Grzywna, B., ... Tychmanowicz U. (2009). Raport o stanie środowiska województwa lubelskiego w 2008 roku. Lublin, Inspekcja Ochrony Środowiska, Wojewódzki Inspektorat Ochrony Środowiska w Lublinie. 